\title{
Human- Indian Grey Mongoose (Herpestes edwardsii) Conflict and Threats to Mongoose in Mirpur District, Azad Jammu and Kashmir, Pakistan
}

\author{
Muhammad Furqan ${ }^{1 *}$, Zulfiqar Ali ${ }^{1}$, Usman Ali², Muhammad Mudassar Shahzad ${ }^{3}$, \\ Bushra Nisar Khan', Waqar Ahmed", Zakir Hussain', Mian Amman Ullah', \\ Nimra Afzal ${ }^{1}$ and Anjum Ara ${ }^{2}$
}

${ }^{1}$ Department of Zoology, University of the Punjab, Lahore, Pakistan

${ }^{2}$ Department of Zoology, Mirpur University of Science and Technology, Mirpur, AJ\&K

${ }^{3}$ Department of Zoology, Division of Science and Technology, University of Education, Lahore

\begin{abstract}
A B S T R A C T
Azad Jammu and Kashmir (AJ and $\mathrm{K}$ ) is blessed with a rich floral and faunal diversity. The Indian grey mongoose (Herpestes edwardsii Hilaire, 1818) is a small carnivore, controls the population of reptiles, ground birds, small mammals, insects, distributed in plain areas of Pakistan and southern AJ and K. The present study aimed to investigate conflict of Indian grey mongoose with human beings. Field surveys were conducted from April 2015-March 2016 in 18 localities of Mirpur, AJ and K. Human mongoose conflict was evaluated following structured questionnaire method. A total of 490 poultry and pets were killed by mongoose during the study period, summing up to an estimated cost of 0.126 million PKRs (784 US\$). The highest $(\mathrm{n}=56)$ depredation was recorded at Naugran and Mehmoodabad locality and the lowest $(\mathrm{n}=14)$ at Rata and Thara localities. Most $(66 \%)$ attacks were observed in summer season; the preferred (32\%) attack timing was the morning time. Three retaliatory killings were reported, 2 at Kalyal and one at Sorakhi locality. Habitat degradation by clearing forests for fuel wood, grazing, agricultural purposes, use of insecticides and retaliatory killing are major threats to the survival of mongoose in the study area. These factors could be controlled through awareness campaigns and better law enforcement in order to conserve this specie.
\end{abstract}

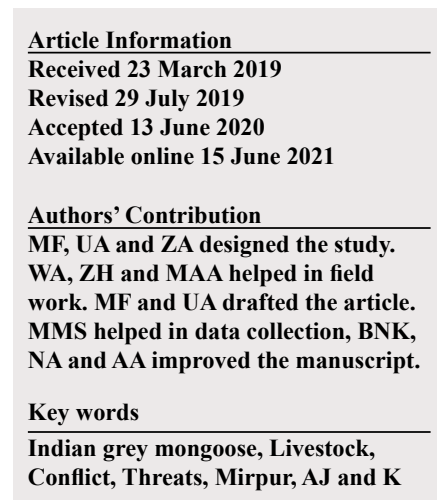

Article Information

Revised 29 July 2019

Accepted 13 June 2020

Available online 15 June 2021

Authors' Contribution

MF, UA and ZA designed the study.

WA, ZH and MAA helped in field

work. MF and UA drafted the article.

NA and AA improved the manuscript.

Indian grey mongoose, Livestock,

Conflict, Threats, Mirpur, AJ and $\mathrm{K}$

\section{INTRODUCTION}

$\mathrm{M}$ ongoose, Herpestes spp. are terrestrial, diurnal solitary hunters that search during the day but mostly active in the early morning and early evening for hunting for food. They may live in burrows or hollow trees to escape the mid-day sun. They often feed on mice, rats and beetles. Red jungle fowl, peafowl, partridges and their eggs are also part of their diet. (Santiapillai et al., 2000; Macdonald, 2006; Francis, 2008).

The Indian grey mongoose (Herpestes edwardsii Hilaire, 1818) has conflicts with humans as they attack and kill domestic poultry (Fedriani et al., 2001). Domestic animals killed by mongoose vary according to species, time of the year, and availability of natural prey. Many humanwildlife conflicts occur even though mongoose actively attempt to avoid people either spatially or temporally.

\footnotetext{
* Corresponding author: furqanzoologist@gmail.com 0030-9923/2021/0005-1603 \$ 9.00/0

Copyright 2021 Zoological Society of Pakistan
}

In natural areas recreational development provides significant supplemental food sources to scavenging animals including waste bins and picnic areas. Species using human recreational areas as a resource can respond to humans directly in several ways. They come for food mostly in the absence of humans (Fedriani et al., 2001; Gilchrist and Otali, 2002).

As human populations grow and transform landscapes, contact with wildlife community increases. Indian grey mongoose is captured by "Jogis" who display snake-mongoose fights, and in many cases, they fight with cobras (Naja naja) in big cities, rural areas and forests themselves (Roberts, 1997). They are believed to prey on snakes and small mammals by using a quick run, moving constantly, and they scan the area for food (Santiapillai et al., 2000).

Mongoose face threats including trade (captured and sold as a pet), their hairs are used for making shaving brushes, paint brushes, and good luck charms (Hanfee and Ahmed, 2000; Shekhar, 2003). Mongoose become worst pest species as they prey on other domestic animals, 
poultry and damage a variety of crops and hence receive retaliatory killing. Due to its extensive population and occurrence especially in human-dominated landscapes there is no risk of extinction but only subjective threats where they provide loss to human population (Jennings, et al., 2010).

\section{MATERIALS AND METHODS}

Study area

District Mirpur is situated in the southern part of Azad Jammu and Kashmir and bounded on the North and East by Kotli District, South by Bhimber and West by Pothohar Plateau. It is located at $33^{\circ} 14.32^{\prime} \mathrm{N}$ and $73^{\circ} 74.74^{\prime} \mathrm{E}$, elevation $460 \mathrm{~m}$, covers an area of $1010 \mathrm{~km}^{2}$. Topographically the district has scattered small hills with plain area and some nullahs. During summer overall climate remains hot, dry and winter is moderate to cold (Ali et al., 2011).

\section{Methodology}

On the basis of geographic conditions study area was divided into 18 localities and in each locality $1.5 \mathrm{~km}^{2}$ area was surveyed. Monthly field surveys were conducted in each study site. Data on conflicts were collected through structured questionnaires and community meetings during field visits. A total of 540 questionnaires were assessed from different study sites. Information was gathered from local shepherds, nomads, old persons, farmers and hunters. Questionnaire was tailored to collect data on humanmongoose conflict, depredation of livestock species. All depredation sites and depredated animals were analyzed, photographed and economic losses caused by mongoose also calculated. GPS and other habitat, topographic features were also recorded. Data were analyzed statistically using MS Excel (ver. 2007) and Statistix 8.1 software.

\section{RESULTS AND DISCUSSION}

\section{Conflicts and threats}

Human wildlife conflict is a serious issue because of long term threat to the wildlife as well as humans. Conflict is created due to attack of Indian grey mongoose on poultry and pets belonging to human beings. Conflicts and threats were assessed through structured questionnaire addressed to the local people, shepherds, hunters and nomads. In response to a question whether mongoose causes damage to local commodity, majority (57\%) of respondents replied positively while $43 \%$ people said that this species does not harm their poultry and pets.

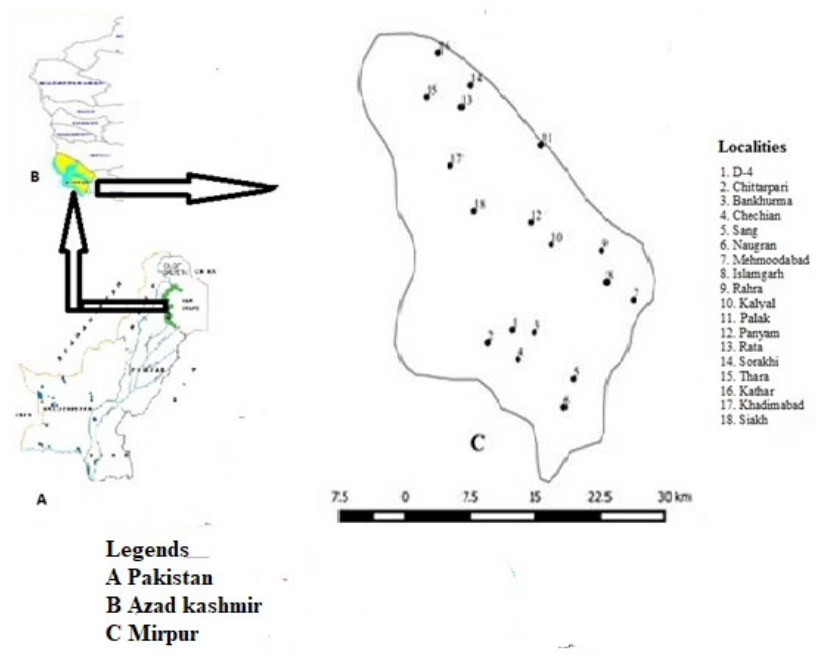

Fig. 1. Map of study area showing different localities.

\section{Depredation of livestock types}

Maximum (93\%) damage was caused to poultry while only $5 \%$ pets were killed by mongoose. Pets mostly included pigeon Columba livia and occasionally a common myna Acridotheres tristis. Egg damage was reported by only $2 \%$ of respondents (Fig. 2).

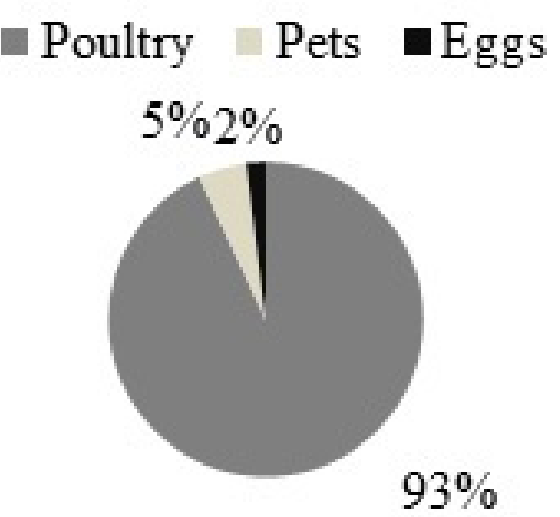

Fig. 2. Damage caused by mongoose to different species in study area.

\section{Attacking time and season of depredation}

According to majority of respondents preferred attacking time of mongoose was during morning (6am to 12 noon) on poultry or other pets, followed by 12 noon to $6 \mathrm{pm}(37 \%)$ while at night ( $6 \mathrm{pm}$ to $6 \mathrm{am})$ only $6 \%$ attacks were recorded (Fig. 3). Data revealed that maximum (66\%) attacks were recorded in summer followed by winter (24\%) and autumn $(6 \%)$ while minimum (4\%) attacks were noted in spring (Fig. 4). Most of the poultry and pet killings $(57 \%)$ were reported in the morning because the animal is 
crepuscular and major part of its daily activities is at the peak at this time (Roberts, 1997). Though seasonal attack pattern was not aligned and in spring season minimum (4\%) attacks were recorded, it may be due to local pattern of land use.

$$
\begin{aligned}
& \text {-6am-12Noon }=12 \text { Noon }-6 \mathrm{pm} \\
& \text {-6pm-12am }=12 \mathrm{am}-6 \mathrm{am}
\end{aligned}
$$

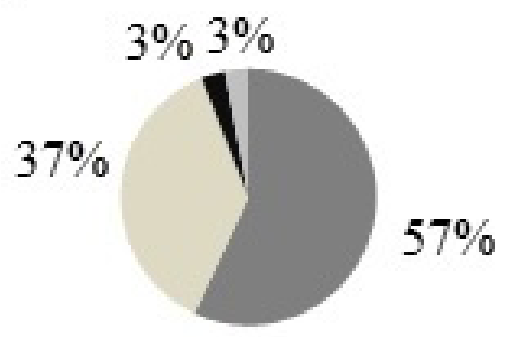

Fig. 3. Attacking time of mongoose.

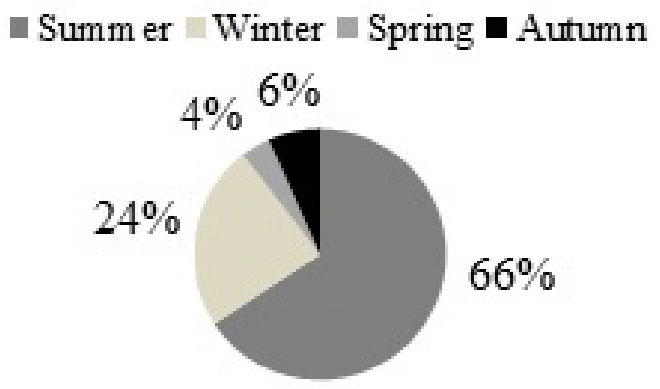

Fig. 4. Seasonal attack pattern of mongoose on poultry and pets in Mirpur.

Number of animals depredated at different study sites

The highest $(n=56)$ depredation was recorded at Naugran and Mehmoodabad localities followed by Kalyal $(n=50)$ due to less availability of natural food and mongoose attack more vigorously on poultry and pets. Whereas the lowest $(n=14)$ depredation was recorded at Rata and Thara localities being near the forest having enriched faunal diversity such as reptiles, birds and insects (Table I).

\section{Estimated economic loss}

Cumulative economic loss caused by the Indian grey mongoose was estimated PKRs 126,000 with maximum (PKRs 118,000; \$737) damage on poultry, and at least PKRs. 75,00 (\$47) to pets. Damage value was estimated according to current average market price of poultry and pets (Fig. 5).

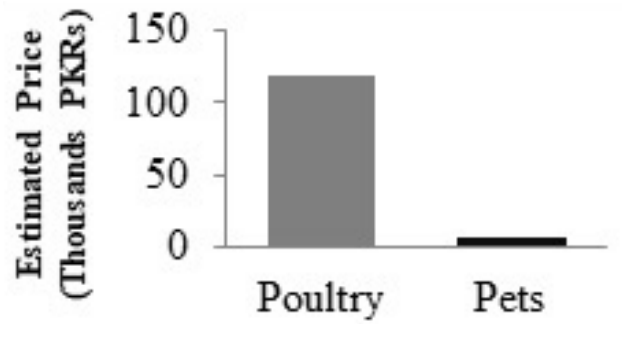

Fig. 5. Economic losses caused by mongoose in Mirpur during study period.

Attitude of the people towards the presence and conservation of mongoose

In order to know the attitude of the local community on the presence of mongoose in their area, majority $(56 \%)$ showed no tolerance of this species around their settlements. These were the people who had experienced poultry or pet loss through mongoose attacks. About $44 \%$ respondents showed a positive attitude towards the mongoose which might be due to the reason that they had never faced any damage or poultry killing caused by mongoose as majority (70\%) of them did not have poultry or pets in their homes (Fig. 6). In response to a question, whether mongoose should be conserved or not, majority of respondents $(56 \%)$ stated that this species should not be conserved while (44\%) agreed that it should be conserved. A total of $33 \%$ respondents were of the opinion that this species should be conserved in protected areas (national parks and game reserves), whereas $11 \%$ respondents were in favor of the conservation of this species even in nonprotected areas (Fig. 7).
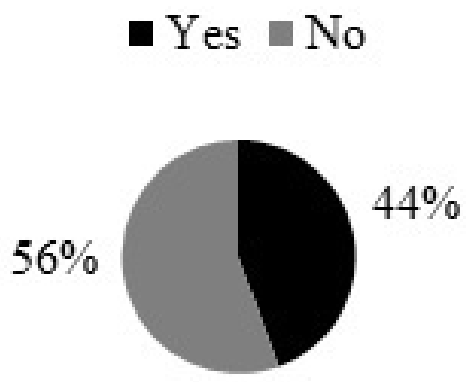

Fig. 6. Attitude of local people for the tolerance of mongoose in their area.

During the summer, the Mangla reservoir reaches the maximum capacity (26,500 ha) and floods adjacent land forcing local wildlife, including the Indian grey mongoose, towards human settlements. This results in increased conflicts between humans and mongooses, caused by 
greater predation on poultry and pets. During the winter, most of the dam water is discharged to meet agricultural and electricity needs of the country, leaving behind a vast open area that can be utilized by mongoose and other wildlife species. This results in mongoose retreating from human settlements and a lowering of human-mongoose conflicts during the winter period.

\section{- Protected Area}

Non Protected Area

- No Conservation

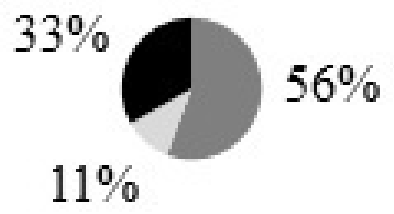

Fig. 7. Attitude of the respondents toward the conservation of mongoose.

The Indian grey mongoose is threatened by retaliatory killing. During the study period, three Indian grey mongoose were killed by local people, two at Palak and one at Sorakhi. As mongoose is a very agile animal, it is hard to be captured hence dogs are used to kill this animal. Local people also use a steel cage with a lure to capture and kill mongoose where attacks are more frequent. Four animals were also found killed in road accidents during the study period. These factors could be controlled by awareness campaigns and effective law enforcement in order to conserve this mongoose species. Better protection of animals and pets would also be helpful to reduce conflict.

Apart from retaliatory killing, Indian grey mongoose may also be threatened by habitat destruction and pollution (Roberts, 1997; Santiapillai et al., 2000). The Indian grey mongoose lives in dry forests (Gilchrist et al., 2009), and the clearance of forests for fuel wood, grazing and agricultural purposes can impact the species. The use of insecticides and the pollution of watercourses can also have serious impacts. However, we found no signs of illegal wildlife trade, captures for staged snake mongoose fights or use in medicine within the study area, as described previously by other researchers (Roberts, 1997; Hanfee and Ahmed, 2000; Shekar, 2003).

Table I. GPS location, altitude, habitat characteristics and number of animals depredated in different study sites.

\begin{tabular}{|c|c|c|c|c|c|c|}
\hline \multirow[t]{2}{*}{ No } & \multirow[t]{2}{*}{ Study site } & \multirow{2}{*}{$\begin{array}{l}\text { Latitude } \\
\text { (N) }\end{array}$} & \multirow{2}{*}{$\begin{array}{l}\text { Longitude } \\
\text { (E) }\end{array}$} & \multicolumn{2}{|c|}{ Altitude Habitat characteristics } & \multirow{2}{*}{$\begin{array}{l}\text { No of animals } \\
\text { depredated }\end{array}$} \\
\hline & & & & (m) & & \\
\hline 1 & D-4 & $33^{\circ} 13.51^{\prime}$ & $73^{\circ} 71.98^{\prime}$ & 360 & Slightly plain having human settlement & 19 \\
\hline 2 & Chittarpari & $33^{\circ} 12.16^{\prime}$ & $73^{\circ} 69.11^{\prime}$ & 330 & Bushy vegetation with small mounds & 28 \\
\hline 3 & Bankhurma & $33^{\circ} 13.25^{\prime}$ & $73^{\circ} 74.62^{\prime}$ & 390 & Blend of hilly and plain areas with human settlement & 43 \\
\hline 4 & Chechian & $33^{\circ} 07.69^{\prime}$ & $73^{\circ} 75.04^{\prime}$ & 250 & Plain area, cultivation of wheat, barley, rice and corn & 39 \\
\hline 5 & Sang & $33^{\circ} 04.11^{\prime}$ & $73^{\circ} 82.02^{\prime}$ & 250 & Plain area, crops are wheat, sugarcane, barley, rice and corn & 16 \\
\hline 6 & Naugran & $33^{\circ} 02.57^{\prime}$ & $73^{\circ} 83.51^{\prime}$ & 240 & Plain, cultivation, with canal banks and human settllement & 56 \\
\hline 7 & Mehmoodabad & $33^{\circ} 16.88^{\prime}$ & $73^{\circ} 87.72^{\prime}$ & 400 & Intermingling high and plain area less populated by humans & 56 \\
\hline 8 & Islamgarh & $33^{\circ} 18.48^{\prime}$ & $73^{\circ} 83.20^{\prime}$ & 380 & Mainly plain and cultivated area & 21 \\
\hline 9 & Rahra & $33^{\circ} 21.80^{\prime}$ & $73^{\circ} 82.59^{\prime}$ & 420 & Bushy vegetation, mostly having plain land some hillocks & 18 \\
\hline 10 & Kalyal & $33^{\circ} 22.45^{\prime}$ & $73^{\circ} 76.57^{\prime}$ & 410 & Plain areas covered with spiny bush vegetation & 50 \\
\hline 11 & Palak & $33^{\circ} 33.02^{\prime}$ & $73^{\circ} 76.68^{\prime}$ & 380 & Blend of small hills and plain fields, where tapering cultivation & 22 \\
\hline 12 & Panyam & $33^{\circ} 24.76^{\prime}$ & $73^{\circ} 74.17^{\prime}$ & 360 & Plain areas, covered with bushy vegetation near Mangla Dam & 22 \\
\hline 13 & Ratta & $33^{\circ} 36.81^{\prime}$ & $73^{\circ} 65.96^{\prime}$ & 480 & Plain and mounds covered with the vegetation & 14 \\
\hline 14 & Sorakhi & $33^{\circ} 37.87^{\prime}$ & $73^{\circ} 61.84^{\prime}$ & 540 & Hillock topography with plain area, less agricultural activities & 18 \\
\hline 15 & Thara & $33^{\circ} 39.11^{\prime}$ & $73^{\circ} 67.10^{\prime}$ & 550 & Small hills with plain area, less agricultural activities & 14 \\
\hline 16 & Kathar & $33^{\circ} 41.23^{\prime}$ & $73^{\circ} 70.52^{\prime}$ & 570 & Small hills with plain area, less agricultural activities & 23 \\
\hline 17 & Khadimabad & $33^{\circ} 30.69^{\prime}$ & $73^{\circ} 64.71^{\prime}$ & 410 & Plain area. Less human settlement, cultivated land & 15 \\
\hline 18 & Siakh & $33^{\circ} 25.93^{\prime}$ & $73^{\circ} 67.48^{\prime}$ & 380 & Less human settlement, plain area, cultivated land & 16 \\
\hline
\end{tabular}




\section{CONCLUSION}

Generally, the people are unaware of the importance, services, ecological and human friendly role of mongoose through controlling population of poisonous snakes, scorpions and other insects. Awareness programs for local communities by the wildlife department and researchers may be organized to minimize wildlife conflict with humans.

\section{ACKNOWLEDGEMENT}

Authors are grateful to Prof Dr. Afsar Mian and Andy Jennings (Small Carnivore Conservation) for improving this manuscript.

\section{Statement of conflict of interest}

The authors have declared no conflict of interest.

\section{REFERENCES}

Ali, Z., Shelly, S.Y. Bibi, F., Joshua, G., Khan, A.M., Khan, B.N. and Akhtar, M., 2011. Peculiarities of Mangla reservoir: Biodiversity with sustainable use options. J. Anim. Pl. Sci., 21: 372-380.

Fedriani, J.M., Fuller, T.K. and Sauvajot, R.M., 2001. Does availability of anthropogenic food enhance densities of omnivorous mammals? An example of coyotes in southern California. Ecography, 24: $325-331$. https://doi.org/10.1034/j.16000587.2001.240310.x

Francis, C.M., 2008. A field guide to the mammals of South-East Asia. New Holland Publishers, London. pp. 293.
Gilchrist, J.S. and Otali, E., 2002. The effects of refuse-feeding on home-range use, group size, and intergroup encounters in the banded mongoose. Can. J. Zool., 80: 1795-1802. https://doi. org/10.1139/z02-113

Gilchrist, J.S. Jennings, A.P. Veron, G. and Cavallini, P., 2009. Family Herpestidae. In: Handbook of the mammals of the world (eds. D.E. Wilson, R.A. Mittermeier),. Volume 1. Carnivores. Lynx, Barcelona. pp. 262-328.

Hanfee, F. and Ahmed, A., 2000. Some observations on India's illegal trade in mustelids, viverrids, and herpestids. In: ENVIS bulletin: Wildlife and protected areas, Mustelids, Viverrids, and Herpestids of India (ed. S.A. Hussain). pp. 113115.

IUCN, 2016. The IUCN red list of threatened species. Version 2016-1. Available www.iucnredlist.org. Accessed: 30 June 2016.

Jennings, A.P., Zubaid, A. and Veron, G., 2010. Home ranges, movements and activity of the short-tailed mongoose (Herpestes brachyurus) on Peninsular Malaysia. Mammalia, 74: 43-50. https://doi. org/10.1515/mamm.2010.001

Macdonald, D.W., 2006. The encyclopedia of mammals. Oxford University Press, Oxford, City.

Roberts, T.J., 1997. The mammals of Pakistan ( $\left.2^{\text {nd }} \mathrm{Ed}\right)$. Oxford University press, London. pp. 191-193.

Santiapillai, C., DeSilv, M. and Dissanayake, S., 2000. The status of mongooses (family Herpestidae) in Ruhuna National Park, Sri Lanka. J. Bomb. Nat. Hist. Soc., 97: 208-214.

Shekhar, S.K., 2003. The status of mongooses in central India. Small Carnivore Conserv., 29: 22-23. 